\title{
'Elaioplasts' identified as lipotubuloids in Althaea rosea, Funkia sieboldiana and Vanilla planifolia contain lipid bodies connected with microtubules
}

\author{
Maria Kwiatkowska*, Dariusz Stępiński, Katarzyna Popłońska, Agnieszka Wojtczak, Justyna Teresa Polit \\ Department of Cytophysiology, University of Łódź, Pomorska 141/143, 90-236 Łódź, Poland
}

\begin{abstract}
"Elaioplasts" observed in Vanilla planifolia, Funkia Sieboldiana and Althaea rosea exhibit all the features characteristic of lipotubuloids earlier described in Ornithogalum umbellatum. They are cytoplasmic domains containing aggregates of lipid bodies connected with microtubules. The immunogold technique confirmed the presence of tubulin in this domain. These structures do not have their own membranes but they are surrounded by a tonoplast at the side of a vacuole since they invaginate into it. In cytoplasm of this domain among lipid bodies there are numerous ribosomes, ER cisternae and vesicles as well as few mitochondria, Golgi structures and microbodies while at older developmental stages there are also autolytic vacuoles. The fact that they are so similar to O. umbellatum lipotubuloids suggest that "elaioplasts" of V. planifolia, F. Sieboldiana and A. rosea can also be named lipotubuloids.
\end{abstract}

Keywords: elaioplasts, immunogold technique, lipid bodies, lipotubuloids, microtubules, tubulin

\section{Introduction}

In many publications the term "elaioplasts" denotes, in accordance with the meaning, plastids containing lipids [1,2]. However, in the past this name was used according to Wakker [3] who was the first to apply it with reference to lipidic structures, often as big as a cell nucleus, which he identified in five Vanilla species. Similar structures were later described in more than 120 species belonging to Monocotyledoneae and Dicotyledoneae (literature data - Tab. 1). The observations in the light microscope showed that some of these plants contain lipidic structures which were definitely not plastids but aggregates of lipid bodies (lipid droplets, oleosomes), e.g. "elaioplasts" in Malva neglecta and Althaea rosea [4], 12 species of Gentiana [5], Dahlia variabilis [6], Ornithogalum umbellatum [7], Haemanthus albiflos [8]([9] - EM observations). However, it should be noted that some "elaioplasts" in plants listed in Tab. 1 are plastids (e.g. in Iris, [10]).

The above literature clearly indicates that the issue is very old, but taking into consideration the papers from the last decade it has become very "hot" once again. Lipid bodies used to be treated as passive structures being only reservoirs of storage substances. However, nowadays they are seen as active

*Corresponding author. Email: kwiat@biol.uni.lodz.pl

This is an Open Access digital version of the article distributed under the terms of the Creative Commons Attribution 3.0 License (creativecommons.org/licenses/ by/3.0/), which permits redistribution, commercial and non-commercial, provided that the article is properly cited.

(c) The Author(s) 2011 Published by Polish Botanical Society organelles playing an important role in lipid homeostasis, intracellular signal transduction and in temporary protein retention. Disturbances in their functioning cause health problems in animals and humans [11-14]. On the other hand, in plants lipids are an important industrial and food product [15,16]. All this led to the revival of interest in these structures. It has been shown that in COS7 fibroblast [17] the surface of lipid bodies is the site of lipid synthesis because it contains an enzyme, diacylglyceroacyltransferase (DGAT) involved in the conversion of diacylglycerols (DAG) into triacylglycerols (TAG). These data were obtained through EM/immunocytochemical studies with the use of coloidal gold. "Elaioplasts" being great aggregates of many lipid bodies seem ideal for this type of research.

Up till now a precise description of light microscopic observations of "elaioplast" development in O. umbellatum has been given by Raciborski [18] and Kwiatkowska [7]. They are present in ovary and stipule epidermis. Ultrastructural studies have shown that they are big cytoplasm domains surrounded not by their own membranes but by a tonoplast because they invaginate into vacuoles. They consist of numerous lipid bodies, covered with a phospholipid monolayer, which contain mainly triacylglycerols and free fatty acids. EM observations at huge magnifications demonstrated that lipid bodies were entwined with microtubules running in different directions and joining them together thus the whole domain moved in a cell as one body with a progressive-rotary movement. These structures were called lipotubuloids as they contain lipid bodies and microtubules [19-27]. In the lipotubuloids in addition to lipid bodies there are numerous ribosomes, ER cisternae and vesicles and few mitochondria, microbodies, Golgi structures and at the late developmental stages autolytic vacuoles containing acid phosphatase and lipase [20]. Moreover, electron microscopic observations 
Tab. 1 Examples of plant family of mono- and dicotyledonous class in which have been identified "elaioplasts".

\begin{tabular}{ll} 
Family & References \\
\hline Monocotyledonous & \\
\hline Liliaceae & {$[7-9,18,28,31-35]$} \\
Iridaceae & {$[10,31]$} \\
Discoraceae & {$[31]$} \\
Orchidaceae & {$[3,10,18,28,31]$} \\
& \\
Dicotyledonous & {$[4,31,36]$} \\
\hline & {$[5,37]$} \\
Malvaceae & {$[38]$} \\
Gentianaceae & {$[39]$} \\
Cucurbitaceae & {$[40]$} \\
Campanulaceae & {$[41]$} \\
Compositeae & {$[41]$} \\
Pirolaceae & \\
Orobanchaceae & \\
\hline
\end{tabular}

revealed actin filaments in them [23]. Lipotubuloids of O. umbellatum form aggregations consisting of a growing numbers of lipid bodies during cell development $[20,25]$. Lipotubuloids appear in intensively growing cells, i.e. in ovary and stipule epidermis, and probably enable intensive growth of cells [25]. However, when the growth of the epidermis is over they gradually disperse into single lipid bodies. The process of disintegration of lipotubuloids is preceded by the disappearance of microtubules joining individual lipid bodies one with another [20,25].

During the first part of our in vivo and ultrastructural studies with the use of the immunogold technique we concentrated on two questions (i) whether "elaioplasts" observed in light microscope in Vanilla planifolia [3], Funkia Sieboldiana [28] and Althaea rosea [4] which are not plastids exhibit the structure charasteristic of $O$. umbellatum lipotubuloids, (ii) whether lipid bodies of these "elaioplasts" are also connected with microtubules. Hence, the aim of this work was to check whether the presence of lipotubuloids is limited only to one species, $O$. umbellatum, or they are more widespread which would prove that the correlation between lipid bodies and microtubules is a more general feature.

\section{Material and methods}

\section{Plant material}

Seeds of Althaea rosea were germinated for four days in darkness at $25^{\circ} \mathrm{C}$ on moisted filter paper in Petri dishes. Plants of Vanilla planifolia and Funkia Sieboldiana were delivered from Botanic Garden in Łódź. Epidermis of Vanilla planifolia young leaves, Funkia Sieboldiana ovaries as well as epidermis of Althaea rosea roots and hypocotyls were used.

\section{Observations in living cells}

Before fixation the epidermis specimens were thoroughly observed in phase light microscope with immersion in order to affirm the presence of "elaioplasts" and their motions.

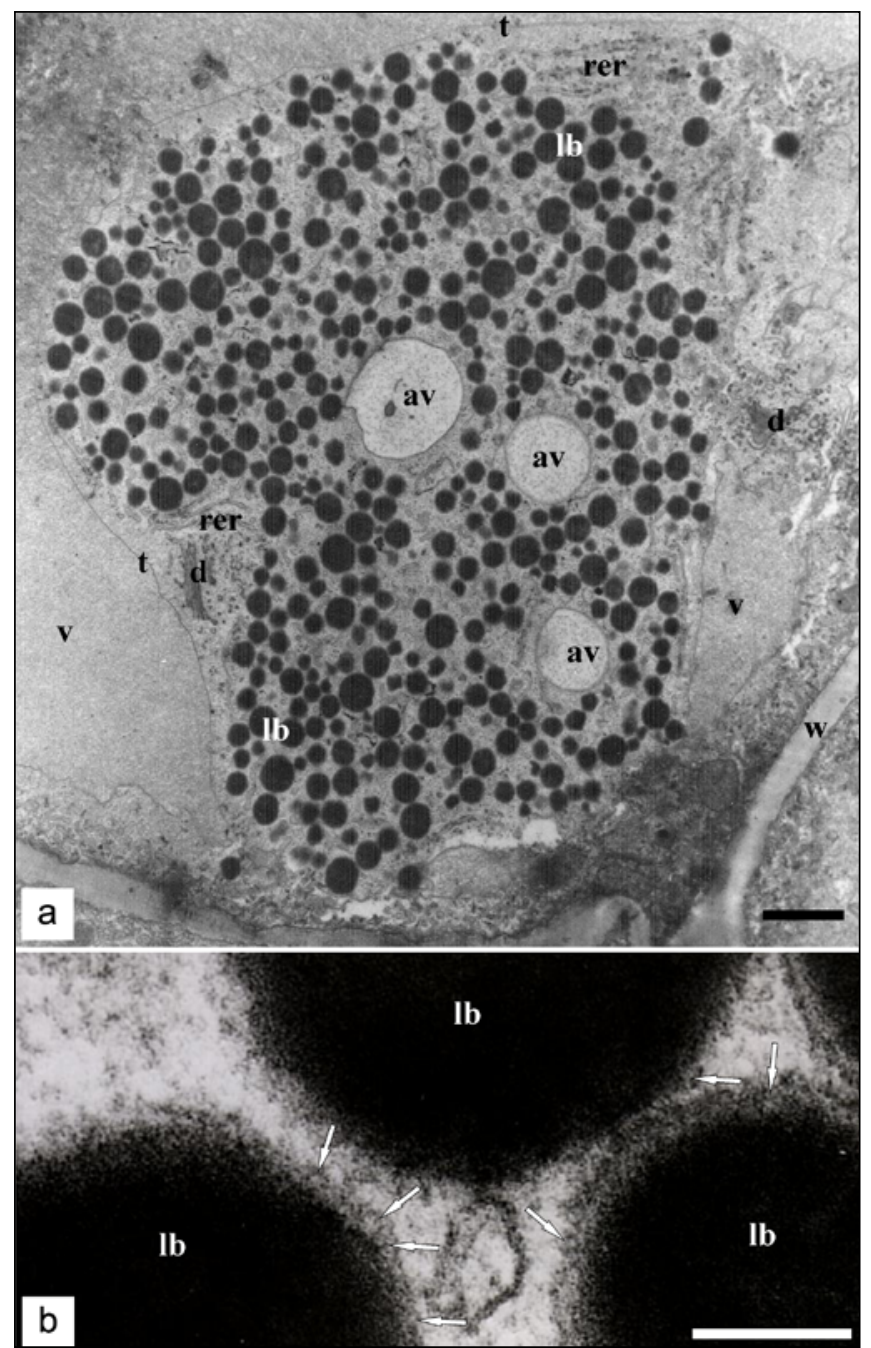

Fig. 1 Fragment of the cell with lipotubuloid in Funkia Sieboldiana ovary epidermis. a Ultrastructure of lipotubuloid; scale bar: $2 \mu \mathrm{m}$. b Lipid bodies entwined by microtubules in cross sections (arrows); scale bar: $200 \mathrm{~nm}$. av - centrally located autolytic vacuole; $\mathrm{d}$ - dictiosom; lb - lipid bodies; $\mathrm{r}$ - ribosomes; rer - rough endoplasmic reticulum; $\mathrm{t}$ - tonoplast; $\mathrm{v}$ - vacuole; $\mathrm{w}$ - cell wall.

\section{Electron microscopy}

Epidermis of plants belonging to the above species was fixed in the mixture of $1 \% \mathrm{OsO}_{4}$ and $2.5 \%$ glutaraldehyde in $0.1 \mathrm{M}$ cacodylate buffer ( $\mathrm{pH} 7.2$ ) for $2 \mathrm{~h}$ and postfixed in $1 \% \mathrm{OsO}_{4}$ in the same buffer at $4^{\circ} \mathrm{C}$ for $3 \mathrm{~h}$. After dehydration in the ethanol series, the material was embedded in the medium consisting of Epon 812 and Spurr's resin. Ultrathin sections $(70 \mathrm{~nm})$ cut using Reichert Joung Ultracut ultra microtome with the glass knife were double stained with uranyl acetate and lead citrate according to Reynolds [29]. The sections were examined and photographed in a JEOL JEM 1010 transmission electron microscope at $80 \mathrm{kV}$ acceleration voltage.

\section{Immunogold technique}

The above material was prepared as it is described in EM section. Freshly cut ultrathin sections were mounted on nickel Formvar coated grids for EM investigations. Prior to immunogold reaction the sections were treated with $10 \%$ hydrogen peroxide for $15 \mathrm{~min}$ to remove osmium which changes antigen structure [30] and washed in distilled water and then in PBS (0.01 M, pH 7.4, Sigma). Air dried grids with the sections were blocked with $0.5 \%$ BSA and $0.05 \%$ Tween 20 in PBS for 


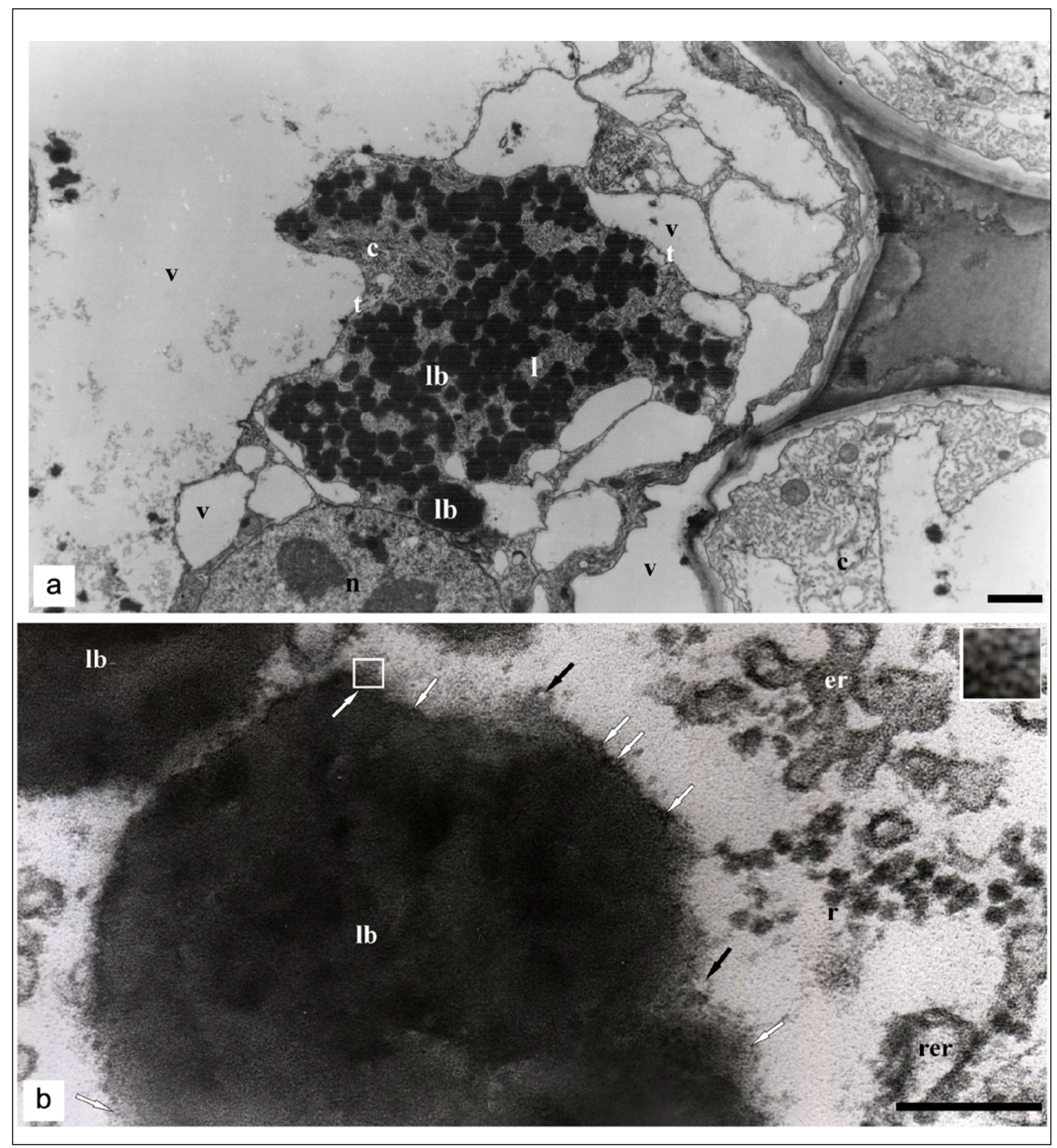

Fig. 2 Fragment of the cell with lipotubuloid in epidermis of young Vanilla planifolia leaves. a Ultrastructure of lipotubuloid; scale bar: $2 \mu \mathrm{m}$. b Lipid bodies with microtubules (white arrows). Black arrows indicate depolimerizing microtubules seen as single subunits. Cross section of the microtubule is viewed at higher magnification of the outlined area; scale bar: $200 \mathrm{~nm}$. c - cytoplasm; er - endoplasmic reticulum; 1 - lipotubuloid; lb - lipid bodies; $\mathrm{n}$ - nucleus; $\mathrm{r}$ - ribosomes; rer - rough endoplasmic reticulum; $\mathrm{t}$ - tonoplast; $\mathrm{v}$-vacuoles.

$20 \mathrm{~min}$ and then dried with tissue-paper, and incubated overnight at $20^{\circ} \mathrm{C}$ with the primary anti- $\alpha$-tubulin mouse monoclonal antibody (T-5168, Sigma) diluted 1:300 in an antibody diluent (pH 8.0, S 0809, DAKO). The material not treated with the primary antibodies was a negative control. After washing 10 times for 5 min each in PBS the grids were incubated with the secondary antibody [anti-mouse IgG conjugated with 10 nm gold (No. EM.GMHL10, Polysciences)] diluted 1:70 in the antibody diluent for $1.5 \mathrm{~h}$ at the same temperature, next the grids were rinsed again in PBS and distilled water (10 times for
5 min each). Ultrathin sections were double stained, examined and photographed as above.

\section{Statistics of a-tubulin immunolabeling}

The percentage of gold grains in two lipotubuloid domains (i) around and within lipid bodies and (ii) rest of the lipotubuloid cytoplasm, in three plant species, was calculated. Thirty lipotubuloid micrographs randomly choosen from 5 roots were analysed. Significance of difference between these two domains was assessed by Student $t$-test taking $p=0.05$ with the use of 


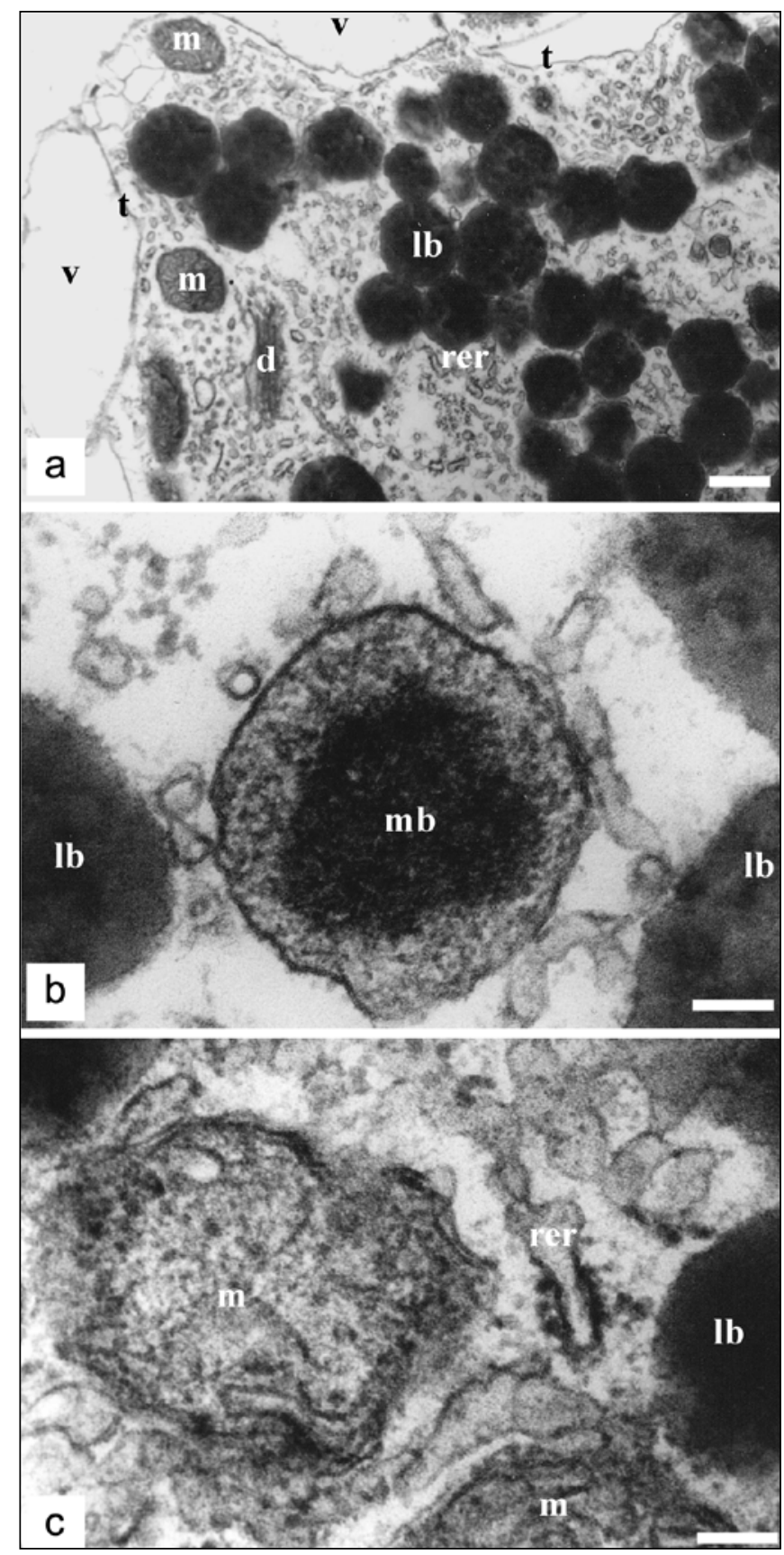

Fig. 3 a-c Fragments of lipotubuloid ultrastructure of Vanilla planifolia leaves with different cell structures. a Scale bar: $500 \mathrm{~nm}$. b,c Scale bar: $100 \mathrm{~nm}$. d - dictiosom; lb - lipid bodies; $\mathrm{m}$ - mitochondrium; $\mathrm{mb}$ - microbodies; rer - rough endoplasmic reticulum; $\mathrm{t}$ - tonoplast; $\mathrm{v}$ - vacuole seen among lipid bodies.

Microsoft Excel 2000; means \pm SE were also estimated.

\section{Results}

\section{Funkia Sieboldiana 'elaioplasts'}

F. Sieboldiana "elaioplasts" are located in ovary epidermis and are the cytoplasm domains containing a great number of lipid bodies. They are spherical structures often localized near a nucleus and mostly surrounded with a tonoplast (Fig. 1a). They look very much like O. umbellatum lipotubuloids, however mitochondria, Golgi structures and microbodies are more often visible at the "elaioplast's" peripheries while ribosomes,
ER cisternae and vesicles are inside the domain among lipid bodies. In the centre of "elaioplast" autolytic vacuoles are visible (Fig. 1a). The lipid bodies of "elaioplasts" are surrounded by microtubules in cross (Fig. 1b) or longitudinal sections. The above observations indicate that F. Sieboldiana "elaioplasts" are lipotubuloids.

\section{Vanilla planifolia 'elaioplasts'}

Under small EM magnification epidermal cells of young leaves contain, like the previous ones, irregular aggregates of lipid bodies surrounded by a tonoplast and connected with parietal cytoplasm and nucleus with a strand of cytoplasm (Fig. 2a). Among lipid bodies there are numerous ribosomes, ER cisternae and vesicles (Fig. 2, Fig. 3) and some Golgi structures (Fig. 3a), microbodies (Fig. 3b), mitochondria (Fig. 3c), and autolytic vacuoles (not demonstrated). Under great magnification microtubules in cross (Fig. 2b) or (less often) longitudinal sections are visible near lipid bodies. These microtubules are not so distinct and numerous as those in O. umbellatum which may result from their weaker stability. Nevertheless, since $V$. planifolia "elaioplasts" exhibit features characteristic of O. umbellatum lipotubuloids they can be treated as lipotubuloids.

\section{Althaea rosea 'elaioplasts'}

They are localized in seedling hypocotyl and root epidermis. They consist of numerous lipid bodies located in the cytoplasmic domain connected with peripheral cytoplasm and in the vicinity of a cell nucleus, at the vacuole side they are surrounded with a tonoplast (Fig. 4a). They contain numerous ribosomes, ER cisternae and vesicles as well as few mitochondria, Golgi structures and microbodies in the domain (Fig. 5). Near "elaioplast" also some plastids containing starch grains are visible (Fig. 4a). At later developmental stages autolytic vacuoles appear (not demonstrated). At great EM magnification cross sections of microtubules (Fig. 4b) touching lipid bodies are visible among them. All this indicates that $A$. rosea "elaioplasts" are lipotubuloids.

\section{Observations with the use of EM immunogold technique}

Immunogold technique with the use of anti- $\alpha$-tubulin antibodies revealed gold grains near lipid bodies, in the cytoplasm between them and adjacent to microtubules in $V$. planifolia (Fig. 6a), A. rosea (Fig. 6b) and F. Sieboldiana (Fig. 6c,d). These images confirm the opinion that "elaioplasts" of these plants

Tab. 2 The presence of $\alpha$-tubulin immunogold labeling in two lipotubuloid domains of three plant species.

\begin{tabular}{lcc} 
Species & \multicolumn{2}{c}{ Frequency [\%] } \\
\cline { 2 - 3 } & $\begin{array}{c}\text { Around and within } \\
\text { lipid bodies }\end{array}$ & $\begin{array}{c}\text { Rest of the lipotubuloid } \\
\text { cytoplasm }\end{array}$ \\
\hline Funkia Sieboldiana $^{*}$ & $82 \pm 7.9$ & $18 \pm 1.5$ \\
Vanilla planifolia $^{*}$ & $59 \pm 4.5$ & $41 \pm 2.8$ \\
Althaea rosea & $47 \pm 3.8$ & $53 \pm 5.9$ \\
\hline
\end{tabular}

The number of gold grains in particular domains is presented as the percentage of the whole pool of grains in the lipotubuloids regarded as $100 \%$. Values represent the mean \pm SE. Significant differences occurred in species marked with *. 

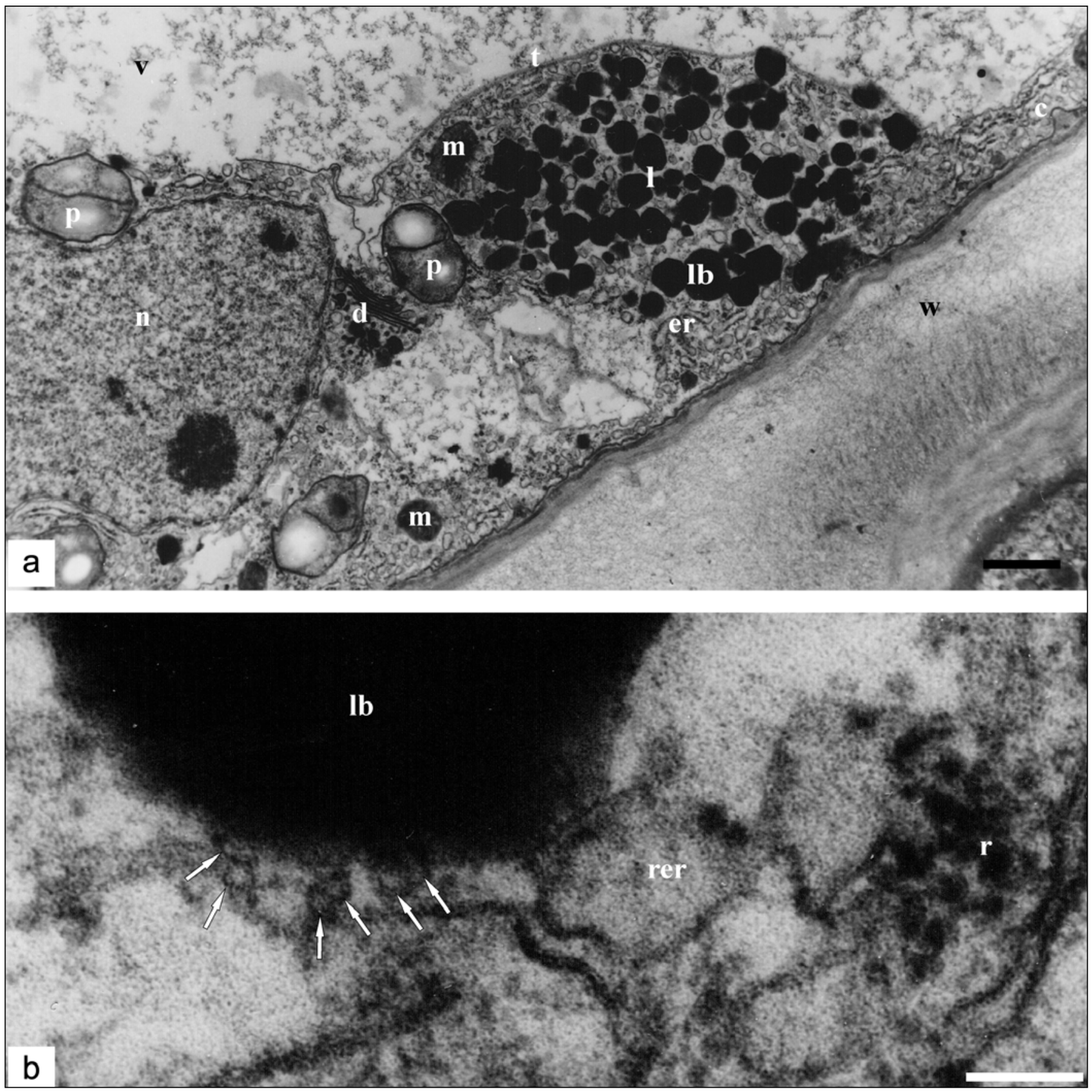

Fig. 4 Fragment of the cell with lipotubuloid in epidermis of Althaea rosea root. a Ultrastructure of lipotubuloid; scale bar: $2 \mu \mathrm{m}$. $\mathbf{b}$ Lipid body entwined by microtubules in cross sections (arrows); scale bar: $100 \mathrm{~nm}$. c - cytoplasm; d - dictiosom; er - endoplasmic reticulum; 1 - lipotubuloid; lb - lipid body; $\mathrm{n}$ - nucleus; $\mathrm{m}$ - mitochondria; $\mathrm{p}$ - plastids; $\mathrm{t}$ - tonoplast; $\mathrm{v}$ - vacuole; $\mathrm{w}$ - cell wall.

are lipotubuloids.

Statistical analysis revealed that in F. Sieboldiana and $V$. planifolia there are statistically significant differences between the gold grain number present within lipid bodies and the rest of the lipotubuloid cytoplasm. This means that the greatest number of $\alpha$-tubulin subunits occurs around and within lipid bodies, which proves that the highest density of microtubules is located in this cell compartment (Tab. 2).

\section{Observations in living cells}

These observations showed that in all studied species the lipotubuloids of granular structure, strongly refracting light performed a rotary and progressive motions with variable dynamic, similarly to lipotubuloids of $O$. umbellatum.

\section{Discussion}

The specificity of the immunogold techinque with the use of anti- $\alpha$-tubulin antibody was first determined by analyzing labeling of O. umbellatum lipotubuloids which are characterized with the presence of many stable microtubules [42]. Microtubules of O. umbellatum lipotubuloids are precisely marked with gold grains (ca. 61\%) both on longitudinal and cross sections of microtubule walls. The other gold grains (ca. 39\%) are outside of microtubules around lipid bodies and most probably mark non-polymerised tubulin (unpublished data). It is commonly known that tubulin occurs in a cell in the polymerised form microtubules, or non-polymerised one as free tubulin subunits [43]. As gold grains marked microtubules, it allows for the conclusion that the immunogold technique is tubulin-specific. 


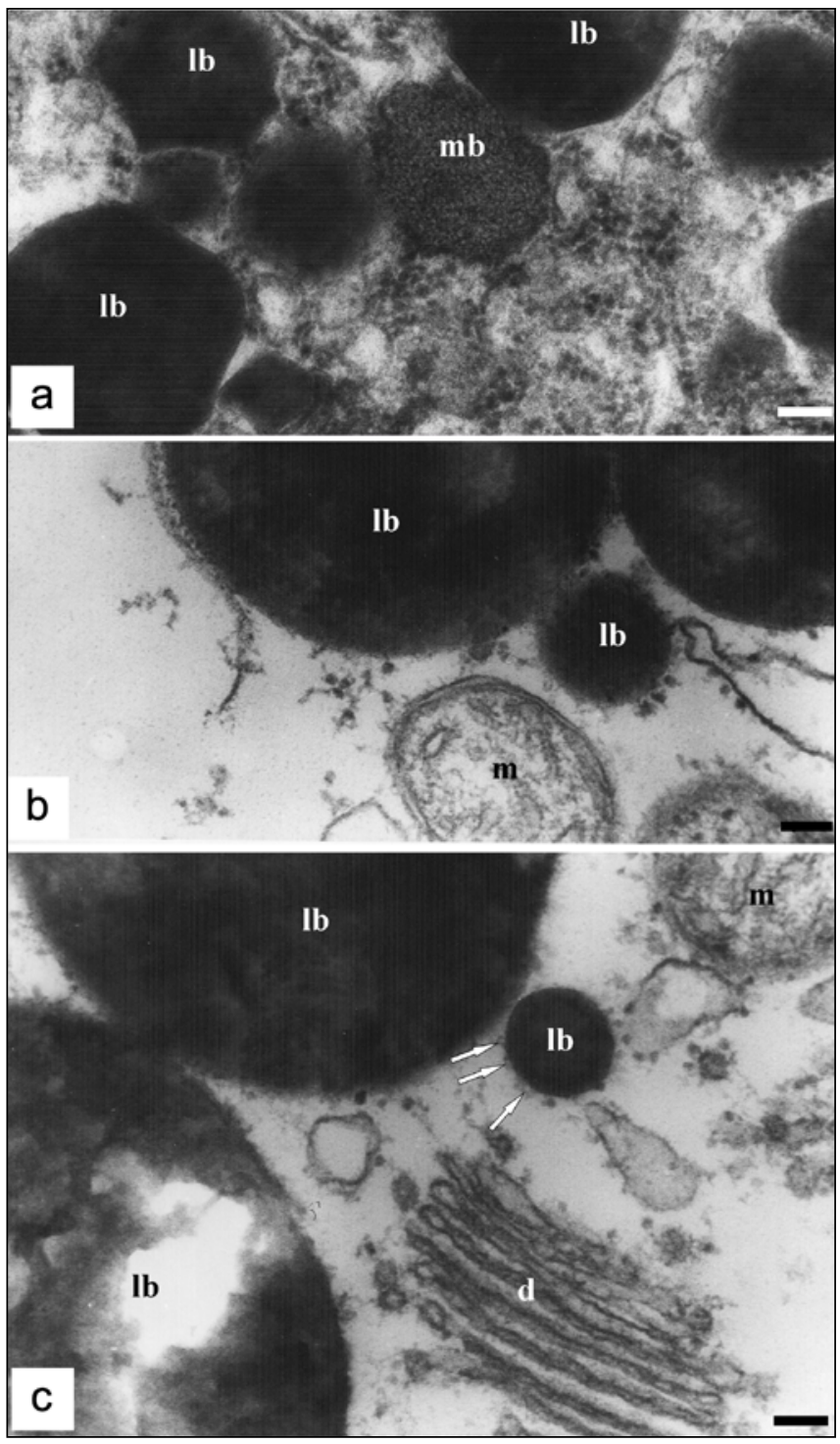

Fig. 5 a-c Fragments of lipotubuloid ultrastructure of Althaea rosea root with different cell structures. lb - lipid bodies; $\mathrm{d}$ - dictiosom; $\mathrm{m}$ - mitochondria; $\mathrm{mb}$ - microbodies, seen among lipid bodies. Scale bars: $100 \mathrm{~nm}$.

Ultrastructural and immunocytochemical analyses with the use of the immunogold technique and anti- $\alpha$-tubulin antibodies show that "elaioplasts" in F. Sieboldiana, V. planifolia and A. rosea exhibit all the features characteristic of O. umbellatum lipotubuloids and are cytoplasmic domains without their own membranes. Great part of their surface is surrounded by a tonoplast because they invaginate into a vacuole. The main components of this domain are great quantity of lipid bodies connected with microtubules. Ribosomes, cisternae and vesicles of ER are located among lipid bodies or at the periphery of the domain. Moreover, few mitochondria, Golgi structures and microbodies being counterparts of peroxisomes and glyoxysomes can also be seen. At later developmental stages autolytic vacuoles appear inside this domain (demonstrated in F. Sieboldiana Fig. 1a). Thus the above described structures do not resemble plastids so the term "elaioplasts" is not adequate. These structures should be called lipotubuloids as they are analogous to O. umbellatum lipotubuloids, although they differ from the latter ones due to a small number of microtubules which are poorly contrasted and mainly in cross sections adjacent to half unit membrane of lipid bodies. This is surely the effect of their lesser stability since apart from whole microtubules there are also broken ones or just single subunits representing tubulin whose presence is also evidenced by immunogold signals in the form of gold grains.

Differences in microtubule stability are well known. They concern different microtubules within a cell as well as the same type of microtubules occurring in different organisms. This is connected with posttranslational modifications of microtubules (PTMs) which change their stability [44-46]. Moreover microtubules can form complexes with microtubule-associated proteins (MAPs) which either increase or decrease their stability [47]. For example cortical microtubules characteristic of dynamically growing cells are more stable than inner ones, however, there are also instable cortical microtubules revealed only after taxol application [48]. In the light of these results the fact that the microtubules from the plants examined in this research are less stable than those of $O$. umbellatum lipotubuloids should not prevent calling their "elaioplasts" - lipotubuloids.

When in 1888 Wakker called "elaioplasts" the lipidic structures, which he observed in Vanilla, he thought about structures producing lipids (in those days this term was not correlated with plastids, only later it became commonly used with regard to them). It turned out that Wakker's intuition was right: O. umbellatum lipotubuloids indeed synthesize lipids since they intensively incorporate tritium labeled palmitic acid ([22]; see documentation also in minireview [26]). EM autoradiography showed that first, after 40 min of incubation, microtubule strands between lipotubuloids became labeled and after $2 \mathrm{~h}$ of incubation this precursor was incorporated into lipid body surface which was covered with a phospholipid monolayer with adjacent microtubules. These observations led to the hypothesis that microtubules might be involved in lipid synthesis which took place at the surface of lipid bodies $[22,26]$. Also Pacheco et al. [49] believe that microtubules are associated with lipid synthesis on the basis of mouse monocyte studies. Whether lipotubuloids of three examined species are the site of lipid synthesis will be investigated in future research. Moreover, the results of Czabany et al. [50] concerning yeast and of Kuerschner et al. [17] about COS7 fibroblast also suggest that the surface of lipid bodies with different anchored proteins is active during lipid synthesis.

The findings of the current research proving that the presence of microtubules around lipid bodies in lipotubuloids is characteristic of other plant species gives the research on functional correlation between lipid bodies and microtubules more general character. It should be added that microtubules play an important role in the generation of progressive-rotary motion of O. umbellatum lipotubuloids [26,27]. Similar motions of lipotubuloids were also observed in the plant species examined in the current work. It is clear that dynamic motion of lipotubuloids in the cell greatly facilitates both incorporation of lipid precursors and enzymatic complexes and spreading of lipid degradation products contained in lipotubuloids. Disappearance of microtubules followed by disintegration of lipotubuloids into singular lipid bodies suggests that microtubules play a role in stabilizing lipotubuloids.

Information can be found in literature that biochemical analyses revealed tubulin in a fraction of isolated lipid bodies [51-53]. It is the more important since microtubules accompany lipid bodies not only in lipotubuloids. The connection between lipid bodies and microtubules has been found in Marchantia paleacea [54], in Lactuca sativa seeds [55] and in Gelidium robustum [56]. In animals there are other elements 


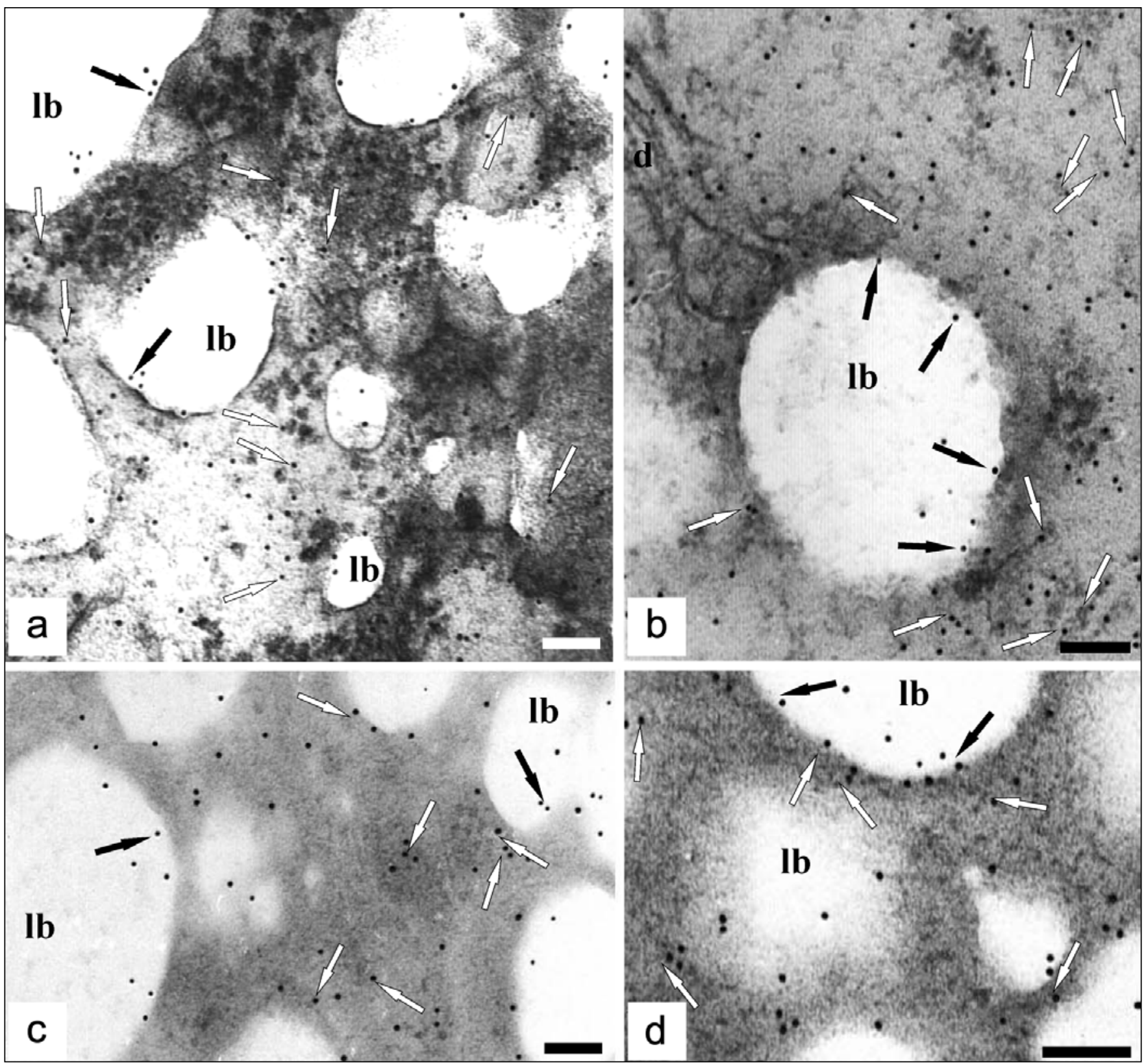

Fig. 6 Detection of a-tubulin with the immunogold technique in: a Epidermis of young Vanilla planifolia leaves; b Epidermis of Althaea rosea root; c,d Epidermis of Funkia Sieboldiana ovary. Black arrows indicate gold grains around lipid bodies, white arrows indicate gold grains at cross and longitudinal sections of microtubules. $\mathrm{lb}$ - lipid bodies. Scale bars: $200 \mathrm{~nm}$.

of cytoskeleton around lipid globules, more stable than microtubules, these are $10 \mathrm{~nm}$ vimentin filaments, identified with immunogold technique during morphogenesis of adipocytes [57-59]. However, in the cumulus-oocyte complexes of mice there are microtubules visible close to lipid droplets [60]. Microtubules are also present at the surface of lipid bodies in human leukocytes [53]. Moreover, observations of LaPointe and Rodríguez [61] indicate that the synthesis or organization of a microtubule system connected with lipid bodies is involved in fat mobilization from the peritoneal fat bodies.

It is worth noting that in the species examined in these studies, similarly as in the case of O. umbellatum lipotubuloids, lipid bodies are accompanied by ribosomes, ER and some mitochondria, Golgi structures and microbodies and autolytic vacuoles containing lipase as well as acid and alcaline phosphatases $[25,26]$. Functional correlations between these organelles and lipid bodies were also observed during lipid transformations and cell functioning in animals [11].

\section{Acknowledgements}

This work is dedicated to memory of Prof. Anna WałekCzarnecka (1890-1978), who was pioneer of "elaioplast" research in our laboratory, in 120 anniversary of birth. This study was supported by the National Committee of Scientific Research, grant No. N N303 359035.

\section{References}

1. Hsieh K, Huang AH. Tapetosomes in Brassica tapetum accumulate endoplasmic reticulum-derived flavonoids and alkanes for delivery to the pollen surface. Plant Cell. 2007;19(2):582-596. doi:10.1105/tpc.106.049049.

2. Hasunuma T, Kondo A, Miyake C. Metabolic pathway engineering by plastid transformation is a powerful tool for production of compounds in higher plants. Plant Biotech. 
2009;26(1):39-46.

3. Wakker ICH. Studien über die Inhaltskörper der Pflanzenzelle. Jahrb Wissensc Bot. 1888;19:423-496.

4. Wałek-Czernecka A, Kwiatkowska M. Elajoplasty ślazowatych. Acta Soc Bot Pol. 1961;31:539-543.

5. Kwiatkowska M. Elajoplasty goryczek cz. II. Obserwacje na materiale utrwalonym. Acta Soc Bot Pol. 1961;30:371-380.

6. Kwiatkowska M. Elajoplasty dalii. Zeszyty Naukowe UŁ. 1963;2(14):81-91.

7. Kwiatkowska M. Investigation on the elaioplasts of Ornithogalum umbellatum L. Acta Soc Bot Pol. 1966;35:7-16.

8. Tourte Y. Observations sur l'infrastructures des elaioplastes chez Haemanthus albiflos. Cr Soc Biol. 1964;158:1712-1715.

9. Tourte Y. Considerations sur la nature, l'origine, et le comportement des elaioplastes chez les Monocotylèdones. Österr Bot Z. 1966;158:1712-1715.

10. Faull AF. Elaioplasts in Iris: a morphological study. J Arnold Arbor. 1935;16:225-267.

11. Goodman JM. The gregarious lipid droplet. J Biol Chem. 2008;283(42):28005-28009. doi:10.1074/jbc.R800042200.

12. Fujimoto T, Ohsaki Y, Cheng J, Suzuki M, Shinohara Y. Lipid droplets: a classic organelle with new outfits. Histochem Cell Biol. 2008;130(2):263-279. doi:10.1007/ s00418-008-0449-0.

13. Guo Y, Cordes KR, Farese RV, Walther TC. Lipid droplets at a glance. J Cell Sci. 2009;122(6):749-752. doi:10.1242/ jcs.037630.

14. Bozza PT, Magalhães KG, Weller PF. Leukocyte lipid bodies - biogenesis and functions in inflammation. Biochim Biophys Acta. 2009;1791(6):540-551. doi:10.1016/j. bbalip.2009.01.005.

15. Lardizabal K, Effertz R, Levering C, Mai J, Pedroso MC, Jury T, et al. Expression of Umbelopsis ramanniana DGAT2A in seed increases oil in soybean. Plant Physiol. 2008;148(1):89-96. doi:10.1104/pp.108.123042.

16. Bhatla SC, Kaushik V, Yadav MK. Use of oil bodies and oleosins in recombinant protein production and other biotechnological applications. Biotech Adv. 2010;28(3):293300. doi:10.1016/j.biotechadv.2010.01.001.

17. Kuerschner L, Moessinger C, Thiele C. Imaging of lipid biosynthesis: how a neutral lipid enters lipid droplets. Traffic. 2008;9(3):338-352. doi:10.1111/j.1600-0854.2007.00689.x.

18. Raciborski M. Elajoplasty liliowatych. Kraków: Akademia Umiejętności; 1895.

19. Kwiatkowska M. Fine structure of the lipotubuloids (elaioplasts) in Ornithogalum umbellatum L. Acta Soc Bot Pol. 1971;40:451-465.

20. Kwiatkowska M. Fine structure of the lipotubuloids (elaioplasts) in Ornithogalum umbellatum in the course of their development. Acta Soc Bot Pol. 1971;40:529-537.

21. Kwiatkowska M. Changes in the diameter of microtubules connected with the autonomous rotary motion of the lipotubuloids (elaioplasts). Protoplasma. 1972;75(4):345-357.

22. Kwiatkowska M. The incorporation of ${ }^{3} \mathrm{H}$-palmitic acid into Ornithogalum umbellatum lipotubuloids, which are a cytoplasmic domain rich in lipid bodies and microtubules. Light and EM autoradiography. Acta Soc Bot Pol. 2004;73:181-186.

23. Kwiatkowska M, Popłońska K, Stepiński D. Actin filaments connected with the microtubules of lipotubuloids, cytoplasmic domains rich in lipid bodies and microtubules. Protoplasma. 2005;226(3-4):163-167. doi:10.1007/ s00709-005-0125-3.
24. Kwiatkowska M, Popłońska K, Stepiński D, Hejnowicz Z. Microtubules with different diameter, protofilament number and protofilament spacing in Ornithogalum umbellatum ovary epidermis cells. Folia Histochem Cytobiol. 2006;44(2):133-138.

25. Kwiatkowska M, Poplonska K, Kazmierczak A, Stepinski D, Rogala K, Polewczyk K. Role of DNA endoreduplication, lipotubuloids, and gibberellic acid in epidermal cell growth during fruit development of Ornithogalum umbellatum. J Exp Bot. 2007;58(8):2023-2031. doi:10.1093/jxb/erm071.

26. Kwiatkowska M, Popłońska K, Stępiński D, Wojtczak A. Lipotubuloids - domains of cytoplasm rich in lipid bodies, entwined by the microtubule system, and active in lipid synthesis. Adv Cell Biol. doi:10.2478/v10052-009-0001-y.

27. Kwiatkowska M, Stepiński D, Popłońska K. Diameters of microtubules change during rotation of the lipotubuloids of Ornithogalum umbellatum stipule epidermis as a result of varying protofilament monomers sizes and distance between them. Cell Biol Int. 2009;33(12):1245-1252. doi:10.1016/j.cellbi.2009.08.012.

28. Zimmermann A. Über die Elaioplasten. Beitr Morphol Physiol Zelle. 1893;1:185-197.

29. Reynolds ES. The use of lead citrate at high $\mathrm{pH}$ as an electron-opaque stain in electron microscopy. J Cell Biol. 1963;17:208-212.

30. Bendayan M, Zollinger M. Ultrastructural localization of antigenic sites on osmium-fixed tissues applying the protein A-gold technique. J Histochem Cytochem. 1983;31(1):101109. doi:10.1177/31.1.6187796.

31. Politis J. Sugli elaioplasti nelle mono- e dicotiledoni. Rendiconti Atti Accad Lincei. 1911;20(1):599-603.

32. Guillermond A. Sur lorigine et la signification des éleoplastes. Cr Soc Biol. 1922;86:437-440.

33. Wóycicki Z. Sur les cristalloides des noyaux at les "eleoplastes" chez Ornithogalum caudatum. B Inter Acad Pol Sci Lett. 1929;25:27-39.

34. Weber F. "Elajoplasten" fehlen den Schließzellen v Hosta plantaginea. Protoplasma. 1955;44:460-463.

35. Thaler I. Studien an plastidenähnlichen Gebiden (Elaioplasten und Sterinoplasten). Protoplasma. 1956;46:743-754.

36. Luxenburgowa A. Recherches cytologiques sur les grain de pollen chez les Malvacees. B Inter Acad Pol Sci Lett. 1928;B:363-395.

37. Kwiatkowska M. Występowanie elajoplastów w skórce rodzaju Gentiana. Zeszyty Naukowe UŁ. 1959;2(5):69-87.

38. Riss MM. Die Antherenhaare von Cyclanthera pedata (Schrad.) und einiger anderer Cucurbitaceen. Flora. 1918;111/112:541-559.

39. Górska-Brylass A. "Elajoplasts" w ziarnach pyłkowych Campanula. Acta Soc Bot Pol. 1962;31:409-418.

40. Beer R. On elaioplasts. Ann Bot. 1909;23(1):63-72.

41. Biedermann W. Der Lipoidgehalt bei Monotropa hypopithys u. Orobanche sporose. Flora. 1920;113:133-154.

42. Kwiatkowska M, Stępiński D, Popłońska K, Wojtczak A, Polit JT. "Elaioplasts” of Haemanthus albiflos are true lipotubuloids: cytoplasmic domains rich in lipid bodies entwined by microtubules. Acta Physiol Plant. 2010;32(6):1189-1196. doi:10.1007/s11738-010-0514-x.

43. Alberts B, Bray D, Lewis J, Raff M, Roberts K, Watson JD. Molecular biology of the cell. 3rd ed. New York: Garland Publishing; 1994.

44. Fukushima N, Furuta D, Hidaka Y, Moriyama R, Tsujiuchi T. Post-translational modifications of tubulin in 
the nervous system. J Neurochem. 2009;109(3):683-693. doi:10.1111/j.1471-4159.2009.06013.x.

45. Ikegami K, Setou M. TTLL10 can perform tubulin glycylation when co-expressed with TTLL8. FEBS Letters. 2009;583(12):1957-1963. doi:10.1016/j.febslet.2009.05.003.

46. Etienne-Manneville S. From signaling pathways to microtubule dynamics: the key players. Curr Opin Cell Biol. 2010;22(1):104-111. doi:10.1016/j.ceb.2009.11.008.

47. Poulain FE, Sobel A. The microtubule network and neuronal morphogenesis: Dynamic and coordinated orchestration through multiple players. Mol Cell Neurosci. 2010;43(1):15-32. doi:10.1016/j.mcn.2009.07.012.

48. Kwiatkowska M, Stępiński D, Polit JT, Popłońska K, Wojtczak A. Microtubule heterogeneity of Ornithogalum umbellatum ovary epidermal cells: non-stable cortical microtubules and stable lipotubuloid microtubules. Folia Histochem Cytobiol. 2011;49(2):285-290.

49. Pacheco P, Vieira-de-Abreu A, Gomes RN, Barbosa-Lima $\mathrm{G}$, Wermelinger LB, Maya-Monteiro CM, et al. Monocyte chemoattractant protein-1/CC chemokine ligand 2 controls microtubule-driven biogenesis and leukotriene B4-synthesizing function of macrophage lipid bodies elicited by innate immune response. J Immunol. 2007;179(12):8500-8508.

50. Czabany T, Athenstaedt K, Daum G. Synthesis, storage and degradation of neutral lipids in yeast. Biochim Biophys Acta. 2007;1771(3):299-309. doi:10.1016/j. bbalip.2006.07.001.

51. Brasaemle D, Dolios G, Shapiro L, Wang R. Proteomic analysis of proteins associated with lipid droplets of basal and lipolytically stimulated 3T3-L1 adipocytes. J Biol Chem. 2004;279(45):46835-46842. doi:10.1074/jbc.M409340200.

52. Cermelli S, Guo Y, Gross SP, Welte MA. The lipid-droplet proteome reveals that droplets are a protein-storage depot. Curr Biol. 2006;16(18):1783-1795. doi:10.1016/j. cub.2006.07.062.

53. Wan HC, Melo RCN, Jin Z, Dvorak AM, Weller PF.
Roles and origins of leukocyte lipid bodies: proteomic and ultrastructural studies. FASEB J. 2007;21(1):167-178. doi:10.1096/fj.06-6711com.

54. Galatis B, Apostolakos P, Katsaros C. Ultrastructural studies on the oil bodies of Marchantia paleacea Bert. I. Early stages of oil-body cell differentiation: origination of the oil body. Can J Bot. 1978;56(18):2252-2267. doi:10.1139/ b78-272.

55. Smith MT. Studies on the anhydrous fixation of dry seeds of lettuce (Lactuca sativa L.). New Phytol. 1991;119(4):575-584.

56. Delivopoulos SG. Ultrastructure of cytocarp development in Gelidium robustum (Gelidiaceae: Gelidiles: Rhodophyta). Mar Biol. 2003;142:659-667.

57. Franke WW, Hergt M, Grund C. Rearrangement of the vimentin cytoskeleton during adipose conversion: formation of an intermediate filament cage around lipid globules. Cell. 1987;49(1):131-141. doi:10.1016/0092-8674(87)90763-X.

58. Almahbobi G, Williams LJ, Hall PF. Attachment of steroidogenic lipid droplets to intermediate filaments in adrenal cells. J Cell Sci. 1992;101(2):383-393.

59. Dvorak AM, Morgan ES, Weller PF. Ultrastructural immunolocalization of basic fibroblast growth factor to lipid bodies and secretory granules in human mast cells. Histochem J. 2001;33(7):397-402.

60. Akkoyunlu G, Korgun ET, Celik-Ozenci C, Seval Y, Demir D, Ustünel I. Distribution patterns of leucocyte subpopulations expressing different cell markers in the cumulusoocyte complexes of pregnant and pseudopregnant mice. Reprod Fertil Dev. 2003;15(7-8):389-395. doi:10.1071/ RD03037.

61. LaPointe JL, Rodríguez EM. Fat mobilization and ultrastructural changes in the peritoneal fat body of the lizard, Klauberina riversiana, in response to long photoperiod and exogenous estrone or progesterone. Cell Tissue Res. 1974;155(2). doi:10.1007/BF00221352. 